\title{
Marine Fisheries in India: Issues of Growth and Instability during the Pre- and Post-WTO Periods
}

\author{
Ranjan Kumar Dash ${ }^{1}$, Rabi N. Patra ${ }^{2}$ \\ 1. Regional Manager, ICICI Lombard General Insurance Company Ltd., Kolkata-700016 \\ 2. Deputy Director, Studies, Gopabandhu Academy of Administration, Bhubaneswar-751023
}

\begin{abstract}
Fisheries constitute an important segment of the national economy and the sub-national economies along the coast line of India. But notwithstanding its contribution to NDP, employment, food and nutritional security, export earnings and high potential for inclusive development, slow growth and high instability remain the grim concerns for development of this sector. This paper analyses the development of fisheries sector in Odisha, a poor coastal state in India, by estimating the trend growth rate and instability indices during the preand post-WTO (World Trade Organisation) periods. The results indicate that both production growth and instability have been lower in the post-WTO period relative to the pre-WTO period. While production growth has slowed down because of lower growth in exports following the WTO conditions, instability has declined mainly due to underproduction. Government provisioning of primary, secondary and tertiary infrastructure is suggested to achieve smooth and high growth of the sector.
\end{abstract}

\subsection{Backdrop}

\section{Introduction}

Fisheries, marine fisheries in particular, constitute an important sub-sector of the primary sector of the Indian economy both at the national and sub-national levels. This segment makes immense contribution to the economy in terms of employment and livelihood, provision of protein and food security, net domestic product and foreign exchange earnings. It has a huge linkage effect in the economy with the backward linkage operating through investment, employment and growth in boat, trawler and net making units and the forward linkage working through those in ice plants, cold storage, processing, transportation, marketing and other related activities.

Although fishing, both marine and inland, is as old as human civilization, its enormous potential as an internationally tradable activity was increasingly felt only during the 1980s. With a maiden start in fisheries as a commercial venture in the 1980 s, this sector has gradually grown over the years to its present giant status. The operations in fisheries have undergone a sea change with the low profile traditional and low key individual and community approaches to fishing wielding to a highly commercial, industrial and corporate business approach. The dynamics of this enterprise is well manifested in its international exposure, technological innovations and technology sharing, alignment to various quality parameters, competitive pricing and greater value addition. Exporters and export houses, the relatively new stakeholders in this business, have played a vital role in protecting fishermen from overproduction and excess supply, providing them price protection and earning foreign exchange for the nation/ state. Consequent upon these developments and innovative and efficient fishing practices, developed harvest and post-harvest infrastructure, growing domestic and international demand for sea food products and fisheries-friendly government policies, the marine fishery sector has experienced spectacular growth since the 1990's.

The introduction of massive economic reforms in India and the associated liberalization, privatization and globalization regime (popularly known as LPG model) of managing the economy since 1991 has opened up the marine fisheries sector to the world market. Looking at the tremendous export and foreign exchange earnings potential of this sector, it was initially thought during the early years of economic reforms that the LPG measures would attract private capital, increase competition, improve efficiency, promote quality production and exports, augment foreign exchange earnings and give a boost to the marine fisheries activities in the economy.

The establishment of WTO in 1995 is a milestone in the realm of institutional arrangement for international trade in goods, services, knowledge and technology. It became functional for the fishery sector in 2001 during the Doha round of talks, nearly one decade after the implementation of economic reforms in India. Like the reform measures implemented by the government of India, the WTO provisions were also intended to promote free flow of goods, services, capital, technical knowhow etc. worldwide with the member countries mandated to grant the most favored nation status to all of them. These two developments were self-reinforcing in nature. Both of them not only promised good returns in terms of capital inflow, technology upgradation, enhanced competition and efficiency and expanded economic opportunities including trade and growth in 
marine fisheries, but have also thrown up new challenges of competition on a unlevel playing field and ruthless exploitation under the guise of WTO provisions of quantitative restriction, anti-dumping duties, restrictive subsidy measures, sanitary and phytosanitary specifications, quality alignment and environmental and technological conditionalities.

Odisha, one of the eastern states of India, is well known for its large mineral deposits and abundant natural resources. A vast coast line is an important gift of nature to the state. The state stands sixth among the states and union territories in India in terms of exposure to sea line with a coast of 480 kilometers. But its share in marine fish catch is hardly 04 per cent and exports of seafood are limited to 03 per cent of the national figures. Although an appreciable trend in marine fish production was established in the state during the 1090s, the resources seem to be largely underutilized despite a high potential. It has to depend on the neighboring states for infrastructure needed for the sector and both production and exports of marine fish continue to remain small and unstable. A clear understanding of the dynamics of the marine fisheries sector, its growth potential and fluctuations in production is necessary for taking corrective measures and putting the sector in right gear.

\subsection{Review of Literature}

Scholarly works on the marine fisheries sector concerning less developed countries like India are relatively scarce and more so in respect of small poor states like Odisha. Although systematic evidence is limited, growing bodies of research studies document the dynamics of development in this sector both at the national and state levels. A brief review of available studies is presented here to assess their contribution to knowledge, identify gaps and indicate scope for further research. The review is organized in two parts. Part-I focuses on studies relating to growth while part-II deals with those concerning instability in both production and export growth in relation to the developments in the aftermath of the WTO.

\subsubsection{Growth Prospects}

Rapid economic growth and the resultant expansion of the domestic retail sector in India have created a large market for fresh, processed and value added fishery products within the country and also new opportunities for international trade in seafood. Supply chains in domestic marketing can be improved by enhancing private investment in value addition and transportation sectors (Sathiadhas et al., 2011). Raghuram and Asopa's study (2008) observed that, Indian marine products are wanted internationally and shrimp being the primary product, there is scope for value addition and increasing other fish varieties. To increase production they suggested the establishment, expansion and upgradation of fishery infrastructure. Pradhan (2005) observed that a growing number of developing countries adopted trade liberalization initiatives to integrate more fully with the global economy since the mid-1980s. Growth of brackish water shrimp farms in the coastal areas is one of the prime examples of this export-driven production system. Shiyani (2002) has made an analysis of districtwise and species-wise growth in marine fisheries in the state of Gujarat. It has been found that the compound growth rates of fish production of almost all the species were positive and significant. Tendulkar's study (2000) pointed out that the liberalisation of restrictions on markets, private sectors, economic activities and progressive integration with the global economy have been the major planks of the wide-ranging economic policy reforms in India since July,1991. They have helped the economy to register higher economic growth including growth of fishermen and making a lasting dent on the long standing problem of abject poverty in India. There are also numerous individual country studies over the past three decades which suggest that trade does seem to create and even sustain higher growth (Bhagwati and Srinivasan, 1999). We hope to make trade an engine of overall economic growth and of development in the fisheries sector which can not only raise income but also reduce

While the above studies concur with growth of fisheries and its potential contribution to economic growth, a study on Nigeria (Oyakhilomen et al.,2013) reveals the absence of causality between fishery production and economic growth. The domestic production of fish in Nigeria was low during the period of study from 1970 to 2011 resulting from the non-optimization of the nation's immense potentials in fish farming which has led to the loss of foreign exchange earnings in the importation of fish to meet local demand. From his study on Kerala fishing scenario, Mohanty (2013) points to the urgency of adopting sea-friendly fishery practices considering the global decline in the marine fisheries production. Some studies have laid a distinct emphasis on the advancement in harvesting and post-harvesting technologies and tapping opportunities of export trade for the growth of marine fisheries. Kerala has been in the forefront in absorbing new technologies in fishing practices and adoptions of the new technologies have led to a massive expansion of the sector to make it a complex structure (Pillai and Katiha, 2004).

Naik (2001) made a study on trends in marine fish landings and marine fish marketing in different maritime districts of Orissa during 1996 to 1999. His findings indicate that marine fish production in Orissa has increased from 38.70 thousand tonnes in 1980-81 to 133.46 thousand tonnes in 1996-97 but it declined to 121.08 thousand tonnes in 2000-01. The State has recorded an average annual growth rate of 8.86 per cent for marine fish production during the period covered under the study from 1996 to 1999 . The study supports the 
hypothesis that marine fish production had increased during the liberalization period and more precisely during the pre-WTO decade.

\subsubsection{Instability and the WTO Impact}

Most of the above studies point to the growth prospects of marine fisheries sector but they are limited to the emerging markets in the context of developments in products and technology. A discussion on the risk factors involved in the growth and distribution of risk among the stakeholders is worth making. Fish and fish products were excluded from the Uruguay Round's Agreement on Agriculture (AoA) and the Agreement on Subsidies governing the fisheries sector. In the Doha Development Agenda(DDA) held in November 2001, the negotiations on clarifying and improving the disciplines of the multilateral trade system with regard to fishing industry subsidies was approved by the WTO ministerial conference. A separate group was also formed to address anti-dumping, subsidies and regional trade agreements. In the initial stages of the negotiations, WTO members identified the principal issues concerning fisheries subsidies and discussed conceptual approaches to new rules (Aswathy et al., 2012). The prohibition of subsidies causing excessive fishing effort and negatively impacting fisheries resources can and shall be reconciled with the important role of fisheries in the economic development of developing countries. Provision of subsidies to the low income resource poor and livelihood fishing activities by fish workers on an individual or family or association basis or by micro enterprises or boat owners shall not be prohibited (Kuruvila et al., 2012). Harper et al., (2012) observed the general consensus that most subsidies to fisheries, particularly fuel subsidies, are harmful to both the economy and the environment. As the WTO struggles to come to an agreement on fisheries subsidies, understanding the position of the negotiating countries is crucial and as we move towards more sustainable regulations, we must ensure that no loopholes exist for countries to evade binding regulations. According to Jinji (2011) the key lies in how the change in subsidies will affect the incentives of workers who engage in fisheries. If a reduction in subsidies causes workers to put more effort into fishing, it may yield unexpected and undesirable results in counties where fisheries resources are not properly managed. Therefore, in designing new regulations on fisheries subsidies at the WTO, the effects of reducing fisheries subsidies should be carefully examined after consideration of the conditions in different countries. Strengthening fisheries resource management will ensure that subsidy reform mitigates overfishing and conserves fisheries resources.

The post-WTO period has witnessed a tightening of food safety and quality standards applied on food products in the developed countries. In the case of the primary importers like the EU, the US and Japan, market actions are expected to have far reaching repercussions and implications for the marine product exports from developing nations (Parvathy and Rajasenan,2012). Sanitary and Phyto-sanitary (SPS) related issues always have problems as far as marine products are concerned and there was a strict ban on import of Indian seafood due to quality and hygiene issues (Jha, 2005). Though the ban was lifted subsequently it resulted in the extensive development of infrastructure like potable water system and effluent treatment plant, flake ice machines, chill rooms, standby generators, laboratory etc. costing over $\$ 25$ million towards upgradation (Kaushik and Shahib, 2001). Since 2000, The issue has been revolving around the use of antibiotics and bacterial inhibitors in shrimps. In the beginning India did not have the infrastructure to detect at Part Per Billion (PPB) level of the chemicals but later on developed the analytical system with liquid chromatographic systems equipped with Mass Spectrometer to detect the banned chemicals in use in aquaculture or otherwise. As there are over 250 chemicals in use, checking for all these chemicals for a particular product has always been a problem faced by the industry (Vijayagopal and Shankar,2012). Defining recession as the significant decline in economic activity spread across the economy lasting more than a few months and normally visible in production, employment, real income, and other indicators which started in 2007-08 (mostly in developed economies), Salim and Narayanakumar (2012) found the existence of a lag in recession especially with regard to food demand . The impact has been noticed since the first quarter of 2009 .

Anti-dumping duty had a major impact on shrimp exports to the US which plummeted from $\$ 409$ million in 2003 before the duty imposition to $\$ 142$ million in 2008. The exports to US have considerably revived after the reduction in the anti-dumping duty from 14.29per cent to 0.79 per cent during 2008-09. Salim (2013) also discussed SPS and indicated that with the huge cost of investment required for the compliance of EU approval and Hazard Analysis and Critical Control Points (HACCP) implementation, the gains weren't significant due to non-capacity utilization of the processing plant and lack of raw materials. The processing plants which have implemented the compliance investment for the EU approval are yet to break even their cost of investment even after $8-10$ years.

Exchange rate instability has a history of wreaking havoc on the economy of the country as has been witnessed recently in the East Asian Crisis of 1998, the Argentinean crisis of 2001 etc. and the falling rupee in 2013. Its adverse impact is high in the export sector. Nair (2006), emphasizes the factors responsible for instability. Following 10 years of constant expansion, 2007 was the first year when shrimp imports into the US witnessed a fall in quantity and value (Punnathara,2009). The year 2008 has also not been significantly different. 
The decline in the strength of the dollar against some major global currencies slowed growth of the US economy and anti-dumping tariff disputes and reduction in consumer confidence have all weakened the world's biggest shrimp importer.

The post-liberalization period scenario of marine products exports registered considerable growth with geographic diversification and emergence of export markets like South East Asia and the Middle East compared to the pre-liberalization period. It is observed that the post-liberalization period exhibits a higher degree of instability as compared to the pre-liberalization period Jeyanthi and Gopal (2012) studied the trend of scampi export and concluded that instability in production has largely influenced the scampi exports. Hence there is a need to increase scampi production and ensure steady supply of raw materials to the seafood processing industry.

In the context of globalisation and challenges of global competition in trade there is an urgent need for policy interventions at the national/state level to meet the increasing domestic and export demand of seafood for the millions and to ensure better livelihood for the fisher folk (Pillai, 2004). Considering the instability of export, a strategy aimed at export diversification in general and devising measures to stabilse supply of seafood products by using research and technology development in particular would be the most appropriate. With regard to price fluctuations of commodities, in addition to price stabilisation policies, appropriate improvement in the product profile with emphasis on value added products which circumvent the price factors including antidumping duties and bonds could provide the way out (Sarada et al., 2006).

\subsection{The Research Problem and Need for the Study}

The foregoing review of literature points to a number of deficiencies of existing research works on the subject. First, the findings are diverse with strikingly different results and recommendations. Second, performance of the marine fisheries sector is influenced by a number of natural, institutional, technological and policy factors while available studies focus mainly at the state level without looking at the policy dynamics impacting on this sector. Third, there is virtually no study on Odisha. Whatever little studies do exist are largely in the nature of reports rather than a systematic analysis of facts and examination of findings both at the state and dis-aggregate level. Since Odisha has a vast coast line with sizable population depending on marine fisheries for their livelihood and the LPG policy and WTO arrangements have a decisive impact on the state economy and the socio-economic conditions of the fishermen community, an indepth study on these issues is worth pursuing. There is thus a need for overcoming research gaps and enriching the existing literature. The present study is a humble attempt in this direction.

\subsection{Objectives, Database, Methodology and Plan of the Study}

The broad objectives of the study are to analyse the present status of fisheries infrastructure, growth of production of fish and instability in such growth with year-to-year variations in respect of both inland and marine fisheries. The study is based on secondary data collected from various publications of MPEDA and governments of India and Odisha. Simple statistical tools such as averages, compound growth rates, coefficient of variation and index of instability have been used to estimate, analyse and interpret the results and draw conclusions and policy implications therefrom. We have used coefficient of variation (CV) for measuring overall variation. But since CV fails to take into account any trend in data while measuring instability in the values of the variable (Mitra, 1980), we have attempted other methods such as those developed by Coppock (1962),Mac-Bean(1966),Massel(1970), Weber and Sievers(1985), Cuddy-Della Valle (1978), Parthasarathy(1984) and Sing and Byerlee(1990). For the purpose of this study, Coppock's instability index has been used because it gives a close approximation of the average year-to-year percentage variation in the value of the variable. Accordingly, the instability index is constructed using the following formula.

$$
\mathrm{V} \log =\frac{1}{\mathrm{~N}-1} \sum\left[\log \mathrm{X}_{\mathrm{t}+1}-\log \mathrm{X}_{\mathrm{t}}-\frac{1}{\mathrm{~N}-1} \sum\left(\log \mathrm{X}_{\mathrm{t}+1}-\log \mathrm{X}_{\mathrm{t}}\right)\right]^{2}
$$

OR

$$
\mathrm{V} \log =\frac{\left[\log \frac{X_{t+1}}{X_{t}}\right]^{2}}{\mathrm{~N}-1}-\mathrm{m}
$$

Where, $\mathrm{N}=$ Number of Years; $\mathrm{X}=$ Value of the perimeter

$M=$ Mean value of the logarithmic first difference.

The study is organised in four sections including the present one. In the following section we present 
an overview of the status of marine fisheries infrastructure and other relevant information in respect of different coastal states of India. Fish production and growth in respect of both inland and marine fisheries of both India and Odisha have been discussed in section-3 with focus on their comparative performance. The time series analysis in this sections has a two period break up i.e., the pre-WTO period from 1990-2001 and the post-WTO period 2002-2013 ${ }^{1}$. Section-4 concludes the paper with some policy implications.

\section{Status of Fishery Resources in Odisha}

Odisha is a maritime State and has considerable scope for development of inland, brackish water and marine fisheries. The State is endowed with a long coastline stretching over $480 \mathrm{~km}$ with a continental shelf area of 24,000 sq km along the Bay of Bengal. It offers tremendous opportunities for development of fresh water, brackish water and marine fisheries with enormous scope for fish production, together with employment and income generation for socio economic prosperity. Fresh water resources of the State are estimated to be 6.75 lakh hectares (ha) comprising of 1.24 lakh ha of tanks/ ponds, 2 lakh ha of reservoirs, 1.80 lakh ha of lakes, swamps \& jheels and 1.71 lakh ha of rivers and canals. The State's brackish water resources are of the order of 4.18 lakh ha with a breakup of 0.79 lakh ha of Chilika Lake, 2.98 lakh ha of estuaries, 32,587 ha of brackish water tanks and 8,100 ha of backwater. The fisheries potential of Odisha is 513,667 MT and about 4 per cent of population (16.26 lakh) depends upon fisheries for their livelihood. Of them, 8.78 lakh depend on inland fisheries and 7.48 lakh on marine fisheries. The fisheries sub-sector contributed about six per cent to the GSDP share of the agriculture sector for the year 2012-13 (Odisha Economic Survey, 2013-14). The status of marine fishery resources in Odisha can be analysed with respect to the production and basic natural infrastructure in the state vis-à-vis those in other major coastal states in the country.

\subsection{Marine Fish Production}

Production of marine fish is the most important indicator of the status of marine fishery sector in any economy. It reflects the size of production and its contribution to total production in the economy and the capacity of the sector as a source of livelihood, employment and income of the people as also of growth for the economy as a whole. Table-1 is self speaking about the marine fish production in Odisha.

\begin{tabular}{|c|c|c|c|}
\hline & Table-1 : Production of Marine Fisheries (2010-11) \\
\hline State & Coast Line (Kms) & Production (000tonnes) & Average Production \\
\hline 1 & 2 & 3 & 4 \\
\hline Gujarat & 1600 & 689 & 0.43 \\
\hline Tamilnadu & 1076 & 405 & 0.38 \\
\hline Andhra Pradesh & 974 & 289 & 0.30 \\
\hline Maharastra & 720 & 447 & 0.62 \\
\hline Kerala & 590 & 560 & 0.95 \\
\hline Odisha & 480 & 133 & 0.28 \\
\hline Karnataka & 300 & 341 & 1.14 \\
\hline West Bengal & 158 & 197 & 1.25 \\
\hline Source: Handbook of Fisheries Statistics, 201 1, Ministry of Agriculture, Govt. of India.
\end{tabular}

Odisha stands the lowest in terms of average production per kilometer of sea line in comparison with other major maritime states. States like Kerala have as high as four times the exploration of Odisha and more importantly, the neighboring state West Bengal has a yield that is 5 times higher than Odisha. Gujarat achieved 0.43 thousand tonnes per kilometer of coast line whereas Odisha with a compact coastline of 480 kilometers achieved only 0.28 thousand tonnes per kilometer. While comparing with the neighboring states, West Bengal recorded as high as 1.25 thousand tonnes per coastline kilometer but the yield in Andhra Pradesh is a little higher than that of Odisha. The marine fisheries sector of Odisha is struggling with an unstable growth in production over the last decade inspite of a number of supports and subsidies.

\subsection{Basic Natural Fishery Infrastructure}

We have seen above that Odisha has the lowest marine fish production in the country. What is more alarming is that the production performance is highly deplorable when we look at the natural advantages available to the state. Table- 2 portrays a comparative picture of the natural advantages of major coastal states in India in terms of coverage of coast line, fishing villages and landing centers.

\footnotetext{
${ }^{1}$ Although WTO was established in 1995, the provisions relating to the fisheries sector were initiated in the Doha Round of discussions in 2001 whereafter the marine fisheries have been considered as a product under Non Agricultural Market Access (NAMA). It is for this reason that we have taken 2001 as the breakeven year.
} 


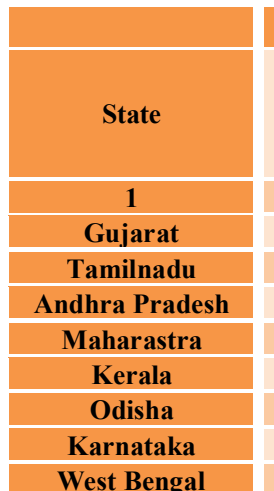

\begin{tabular}{|c|c|c|c|c|c|}
\hline \multicolumn{6}{|c|}{ Table 2 : Marine Fisheries Resources of India } \\
\hline Coast Line(Kms.) & $\begin{array}{l}\text { No of } \\
\text { Fishing } \\
\text { Villages } \\
\text { (FV) }\end{array}$ & $\begin{array}{l}\text { No.of Landing } \\
\text { Centres(LC) }\end{array}$ & $\begin{array}{l}\text { Coast Line per } \\
\text { Landing } \\
\text { Centre }\end{array}$ & $\begin{array}{c}\text { FV Dependency } \\
\text { on } \mathrm{LC}\end{array}$ & $\begin{array}{l}\text { Ratio of FV to } \\
\text { Coastline }\end{array}$ \\
\hline 2 & 6 & 3 & 4 & 5 & 7 \\
\hline 1600 & 247 & 121 & 13.22 & 2.04 & 0.15 \\
\hline 1076 & 573 & 407 & 2.64 & 1.41 & 0.53 \\
\hline 974 & 555 & 353 & 2.76 & 1.57 & 0.57 \\
\hline 720 & 456 & 152 & 4.74 & 3.00 & 0.63 \\
\hline 590 & 222 & 187 & 3.16 & 1.19 & 0.38 \\
\hline 480 & 813 & 73 & 6.58 & 11.14 & 1.69 \\
\hline 300 & 144 & 96 & 3.13 & 1.50 & 0.48 \\
\hline 158 & 188 & 59 & 2.68 & 3.19 & 1.19 \\
\hline
\end{tabular}

Source: Marine Census,2005 (Annual Report,2012-13 DAHD, Ministry of Agriculture, Govt. of India).

Note: FV= Fishing Village, $\mathrm{LC}=$ Landing centre

It can be seen from the above table that Odisha has the highest number of fishing villages in the country which means a fishing friendly culture is naturally existing across the coast line of the state with maximum dependency of 1.69 villages per kilometer as against around 0.5 village per kilometer of coastline in other coastal fishery rich states. This clearly shows the adequacy in terms of workforce but the potentiality is far behind other states due to lack of infrastructure. The Landing Centers, which are the base infrastructure for marine fish catch, are very few in the state. It can be seen from the above table that the average coastline per landing center in Odisha is 6.58 which is the second highest in the country next to Gujarat. For all other states it varies between 3-5 kilometers which is almost half to that of Odisha. It means the fishermen have to travel at least seven kilometers to land the catch and then transporting to its place of destination is a difficult task over and above the safety in anchoring the vessel that away. Keeping aside the discussion about ideal infrastructure, it shows the gross inadequacy of infrastructure in Odisha in comparison to other fishery rich states. Justifying the same the fishing village dependency on landing center is the standalone highest with huge margin. Odisha is having as much as 11 fishing villages depending on a landing center in comparison to that of Kerala and Tamilnadu where only one fishing village is depending on a landing center.

Another dimension is export infrastructure. It is equally inadequate as still major sea shipments, specifically frozen shipments, are sent through ports of neighboring states i.e., Kolkata and Visakhapatnam. Paradip, the major port of Odisha, is still having inadequate facilities to cater to the export logistics need of the state. The other port of Odisha at Gopalpur is inactive in terms of regular vessels and the port of Dhamra is under renovation since long. Potentiality of Paradip port needs to be developed in terms of vessel calling along with arrangement for sufficient containers with special focus on viability of frozen container. Till date not a single privatized modern container terminal is present in the state of Odisha. The other way to look at is the cost of pre-export shipment which is presently higher as both the ports in neighboring states are around 500 kilometers away from the state capital Bhubaneswar whereas Paradip is hardly 100 kilometers away.

Attention of government authorities and planners need to be drawn towards creation and expansion of primary infrastructure for enabling the fishermen to go for fishing smoothly increasing the number of fishing days, raising fish production and reducing the seasonal supply gap in a perishable product like fish. The expansion of secondary infrastructure like fishing gears, preservation equipments while on sea, information on fish stock and weather alert etc will help to ensure stability in performance. Creation of tertiary infrastructure in the forms of ice plants, pre-processing centers, frozen transportation chain and fair market regulations will play a vital role in capitalizing the produce. Summing up the discussion it can be concluded that Odisha has great potentiality in terms of natural resource of long coastline and number of fishing villages evolved through generations but its marine fish production proves its underperformance when compared to similar states for many reasons including inadequacy of basic infrastructure which need to be expanded for increasing employment, providing livelihood security and making a significant contribution to economic growth.

\section{Fish Production and Growth During pre- and post-WTO periods}

The fundamental basis for analysing the performance, problems and prospects of any sector of economic activity is obviously production. In this section we intend to discuss the output growth performance of the marine fishery sector during the pre- and post-WTO periods.

\subsection{The All India Scenario}

As a backdrop to in-depth analysis we begin with the production and growth of marine and inland fisheries at the national level. Relevant data are given in Table-3 below. 


\begin{tabular}{|c|c|c|c|c|c|c|c|c|c|c|c|}
\hline \multicolumn{12}{|c|}{ Table-3 : Fish Production in India (in'000tonns) } \\
\hline \multirow[b]{2}{*}{ Period } & \multirow[b]{2}{*}{ Year } & \multicolumn{5}{|c|}{ Marine } & \multicolumn{5}{|c|}{ Inland } \\
\hline & & Production & AGR & CAGR & $\mathrm{CV}$ & $\begin{array}{c}\text { Instab } \\
\text { ility }\end{array}$ & Production & AGR & CAGR & $\mathrm{CV}$ & $\begin{array}{c}\text { Instabi } \\
\text { lity }\end{array}$ \\
\hline 1 & 2 & 3 & 4 & 5 & 6 & 7 & 8 & 9 & 10 & 11 & 12 \\
\hline \multirow{12}{*}{$\begin{array}{l}5 \\
\vdots \\
0 \\
0 \\
0 \\
0 \\
0 \\
0 \\
0 \\
0 \\
0\end{array}$} & 1990 & 2275 & 0.00 & \multirow{12}{*}{1.78} & \multirow{12}{*}{0.09} & \multirow{12}{*}{1.40} & 1402 & 0.00 & \multirow{12}{*}{6.07} & \multirow{12}{*}{0.22} & \multirow{12}{*}{1.66} \\
\hline & 1991 & 2300 & 1.10 & & & & 1536 & 9.56 & & & \\
\hline & 1992 & 2447 & 6.39 & & & & 1710 & 11.33 & & & \\
\hline & 1993 & 2576 & 5.27 & & & & 1789 & 4.62 & & & \\
\hline & 1994 & 2649 & 2.83 & & & & 1995 & 11.51 & & & \\
\hline & 1995 & 2692 & 1.62 & & & & 2097 & 5.11 & & & \\
\hline & 1996 & 2707 & 0.56 & & & & 2242 & 6.91 & & & \\
\hline & 1997 & 2967 & 9.60 & & & & 2381 & 6.20 & & & \\
\hline & 1998 & 2950 & -0.57 & & & & 2438 & 2.39 & & & \\
\hline & 1999 & 2696 & -8.61 & & & & 2602 & 6.73 & & & \\
\hline & 2000 & 2852 & 5.79 & & & & 2823 & 8.49 & & & \\
\hline & 2001 & 2811 & -1.44 & & & & 2845 & 0.78 & & & \\
\hline \multirow{12}{*}{ 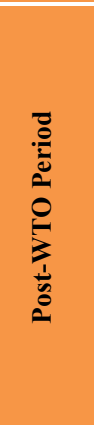 } & 2002 & 2830 & 0.68 & \multirow{12}{*}{1.62} & \multirow{12}{*}{0.07} & \multirow{12}{*}{1.09} & 3126 & 9.88 & \multirow{12}{*}{5.03} & \multirow{12}{*}{0.20} & \multirow{12}{*}{1.49} \\
\hline & 2003 & 2990 & 5.65 & & & & 3210 & 2.69 & & & \\
\hline & 2004 & 2941 & -1.64 & & & & 3458 & 7.73 & & & \\
\hline & 2005 & 2779 & -5.51 & & & & 3526 & 1.97 & & & \\
\hline & 2006 & 2816 & 1.33 & & & & 3756 & 6.52 & & & \\
\hline & 2007 & 3024 & 7.39 & & & & 3845 & 2.37 & & & \\
\hline & 2008 & 2920 & -3.44 & & & & 4207 & 9.41 & & & \\
\hline & 2009 & 2978 & 1.99 & & & & 4638 & 10.24 & & & \\
\hline & 2010 & 3104 & 4.23 & & & & 4894 & 5.52 & & & \\
\hline & 2011 & 3250 & 4.70 & & & & 4981 & 1.78 & & & \\
\hline & 2012 & 3375 & 3.85 & & & & 5295 & 6.30 & & & \\
\hline & 2013(P) & 3430 & 1.63 & & & & 5632 & 6.36 & & & \\
\hline
\end{tabular}

Source : Annual Report,2012-13 DAHD, Ministry of Agriculture, Govt. of India

It can be read off the table that inland fish production in India during the pre-WTO period has more than doubled from 1402000 tonnes in 1990 to 2845000 tonnes in 2001 . The trend continued during the postWTO period and production reached 5632000 tonnes in 2013. This implies that the inland fish production has grown parallel with the growth in population to meet the increasing demand for consumption. But the situation is reverse in the case of marine fish production. In the pre-WTO period, production increased remarkably and consistently from 2275000 tonnes in 1990 to 2967000 tonnes in 1997, but during 1998-2001 it is marked by year-to-year fluctuations. It can be seen from the table that production fell from 2967000 tonnes in 1997 to 2950000 tonnes in 1999 whereafter it increased to 2852000 tonnes in 2000 and again fell to 2811000 tonnes in 2001. Estimates show that marine fish production exhibited wide variations in average annual growth rates during the pre-WTO period (Col.4).

In the post-WTO period i.e., beyond 2001 the fluctuations continued unabated. Production of marine fish increased from 2811000 tonnes in 2001 to 2830000 tonnes in 2002 and to 2990000 tonnes in 2003 whereafter it fell to 2941000 tonnes in 2004 and to 2779000 tonnes in 2005 . There occurred some improvement in 2006 and 2007 with production increasing to 2816000 tonnes and 3024000 tonnes respectively. However production dipped to 2920000 tonnes in 2008 but rose continuously to 2978000 tonnes in 2009,3104000 tonnes in 2010, 3250000 tonnes in 2011, 3375000 tonnes in 2012 and 3430000 tonnes in 2013.

An anatomical analysis of the data given in Table-3 reveals that marine fish production has grown to the extent of 30 per cent during the pre-WTO period as against 21 per cent during the post-WTO period. With greater infrastructure, better harvesting facilities and opening of markets, the marine fisheries was expected to grow faster both in absolute terms and relative to the inland fishery sector but actually it experienced slower growth. This scenario is depicted in Figure-1. 


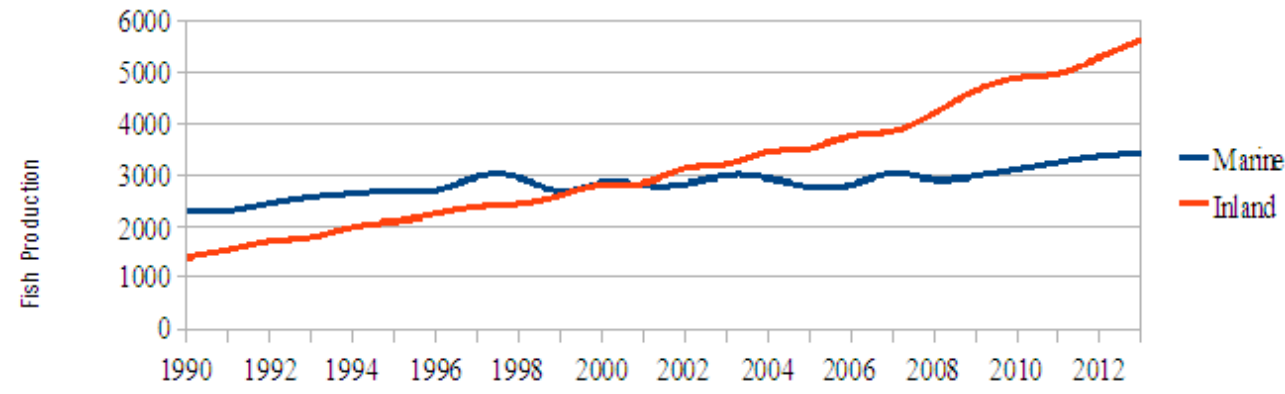

Year

During the pre-WTO period, the thin line showing inland fish production lied below the thick line showing marine fish production. This trend continued till the year 2001 but was reversed in the post-WTO period i.e., the thin line of inland fish production is above the thick line showing marine fish production. In fact, inland fish production has shown a linear growth rate, but the marine fish production has shown a remarkably volatile behavior during both the periods.

As depicted in the above figure, the gap between the two lines have developed conversely with the gap increasing during the post-WTO era. While the Inland fish production continued to grow at a higher rate, the marine fish production experienced slow growth rate during the post-WTO period. This suppressed growth could be due to the impact of various WTO conditions imposed from time to time after the finalisation of the NAMA in the Doha round of discussions in 2001.

In order to have a critical analysis of the fishery sector we have computed the annual growth rate (AGR) and compound annual growth rate(CAGR) of production in respect of both inland and marine fisheries for the state of Odisha and the country as a whole concerning the pre- and post-WTO periods. The AGR of production of inland fish in the pre-WTO period has been found to have varied between 0.78 and 11.51 as against 1.78 and 10.24 in the post-WTO period. The CAGR, CV and instability in production have been estimated to be $6.07,0.22$ and 1.66 respectively in the pre-WTO period and the respective values workout to 5.03, 0.20 and 1.49 for the post-WTO period. In the case of marine fish the AGR of production ranges between 8.61 and 9.60 in the pre-WTO period and between -5.51 and 7.39 in the post-WTO period . CAGR, CV and instability in production have been found to be little higher at 1.78, 0.09 and 1.40 respectively in the pre-WTO period in comparison to $1.62,0.07$ and 1.09 for the post-WTO period.

Two conclusions can be drawn from the analysis presented above. First, the growth rate, variation in growth rate and instability in production have been observed to be higher in the case of inland fish than marine fish for both pre- and post-WTO periods. Second, they are higher in the pre-WTO period than in the post-WTO period for both inland and marine fishery sectors. Variability and instability in production may be linked to the volume and growth rate of production. When production growth slows down so do the variability and instability. Higher production growth in inland fish relative to marine fish may be the plausible reason for higher variability and greater instability of the former as compared to the latter. Further, lower growth in production of both inland and marine fish in the post-WTO situation reflects the limits to growth in the fishery sector. For the marine fish sector it may be additionally due to the growing environmental concerns and awareness as also of the WTO conditionalities.

\subsection{The Odisha Scenario}

As noted above, Odisha is a maritime state with a rich coast line, favorable continental shelf and has enough potentiality in terms of marine fish production for making it a leader in international business and earning foreign exchange for the state. The state has as many as 14 major rivers, innumerable ponds, large canals and streams which provide enormous opportunities for inland fish production. The details of amount, composition, growth rate and instability in fish production in Odisha are given in Table-4 


\begin{tabular}{|c|c|c|c|c|c|c|c|c|c|c|c|}
\hline \multicolumn{12}{|c|}{ Table-4 : Fish Production in Odisha (in'000tonn) } \\
\hline \multirow[b]{2}{*}{ Period } & \multirow[b]{2}{*}{ Year } & \multicolumn{5}{|c|}{ Marine } & \multicolumn{5}{|c|}{ Inland } \\
\hline & & Production & AGR & CAGR & $\mathrm{CV}$ & $\begin{array}{c}\text { Instab } \\
\text { ility }\end{array}$ & Production & AGR & CAGR & $\mathrm{CV}$ & $\begin{array}{c}\text { Instab } \\
\text { ility }\end{array}$ \\
\hline 1 & 2 & 3 & 4 & 5 & 6 & 7 & 8 & 9 & 10 & 11 & 12 \\
\hline \multirow{12}{*}{ 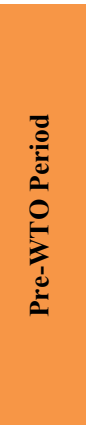 } & 1990 & 78 & 0.00 & \multirow{12}{*}{3.74} & \multirow{12}{*}{$\begin{array}{c}0.2 \\
0\end{array}$} & \multirow{12}{*}{4.19} & 76 & 0.00 & \multirow{12}{*}{5.15} & \multirow{12}{*}{$\begin{array}{c}0.2 \\
4\end{array}$} & \multirow{12}{*}{3.25} \\
\hline & 1991 & 78 & 0.38 & & & & 81 & 6.44 & & & \\
\hline & 1992 & 95 & 21.53 & & & & 88 & 8.82 & & & \\
\hline & 1993 & 119 & 25.62 & & & & 94 & 6.69 & & & \\
\hline & 1994 & 104 & -12.94 & & & & 128 & 36.90 & & & \\
\hline & 1995 & 123 & 18.25 & & & & 135 & 5.00 & & & \\
\hline & 1996 & 123 & 0.25 & & & & 135 & 0.05 & & & \\
\hline & 1997 & 133 & 8.33 & & & & 143 & 6.42 & & & \\
\hline & 1998 & 156 & 16.95 & & & & 152 & 6.22 & & & \\
\hline & 1999 & 124 & -20.34 & & & & 160 & 4.91 & & & \\
\hline & 2000 & 126 & 1.29 & & & & 135 & -15.38 & & & \\
\hline & 2001 & 121 & -3.85 & & & & 139 & 2.40 & & & \\
\hline \multirow{12}{*}{  } & 2002 & 114 & -5.94 & \multirow{12}{*}{0.32} & \multirow{12}{*}{$\begin{array}{c}0.0 \\
6\end{array}$} & \multirow{12}{*}{1.72} & 168 & 21.29 & \multirow{12}{*}{4.70} & \multirow{12}{*}{$\begin{array}{c}0.1 \\
7\end{array}$} & \multirow{12}{*}{2.40} \\
\hline & 2003 & 115 & 0.98 & & & & 174 & 3.65 & & & \\
\hline & 2004 & 117 & 1.63 & & & & 189 & 8.77 & & & \\
\hline & 2005 & 122 & 4.32 & & & & 194 & 2.20 & & & \\
\hline & 2006 & 122 & 0.23 & & & & 203 & 4.95 & & & \\
\hline & 2007 & 128 & 4.85 & & & & 215 & 5.58 & & & \\
\hline & 2008 & 131 & 2.05 & & & & 219 & 1.93 & & & \\
\hline & 2009 & 135 & 3.61 & & & & 239 & 9.43 & & & \\
\hline & 2010 & 129 & -4.54 & & & & 241 & 0.83 & & & \\
\hline & 2011 & 133 & 3.21 & & & & 253 & 4.72 & & & \\
\hline & 2012 & 114 & -14.37 & & & & 268 & 5.87 & & & \\
\hline & 2013(P) & 118 & 3.51 & & & & 292 & 9.08 & & & \\
\hline
\end{tabular}

Source : Ddepartment of Animal Husbandry and dairying, Govt. of Odisha website downloaded on 05.10.13

As can be seen in the table, the production of inland fish has increased consistently since 1990 but the rate has slowed down and variance and instability lowered in the post-WTO period in comparison to the preWTO period. The CAGR, CV and instability have been estimated to be 5.15, 0.24 and 3.25 respectively in the pre-WTO period but the respective values are significantly lower at 4.70, 0.17 and 2.40 in the post-WTO period. The slowing down in growth and decline in variance and instability in the post-WTO period relative to the preWTO period is more remarkable in the case of marine fish when compared with the inland fishery sector. In the pre-WTO period the CAGR, CV and instability have been found to be 3.74, 0.20 and 4.19 respectively as against $0.32,0.06$ and 1.72 in the post-WTO period for the marine fishery sector. The behavior of production of inland and marine fish in Odisha as depicted in Table-4 is illustrated in Figure-2.

Figure-2

Trend of Fish production of Odisha

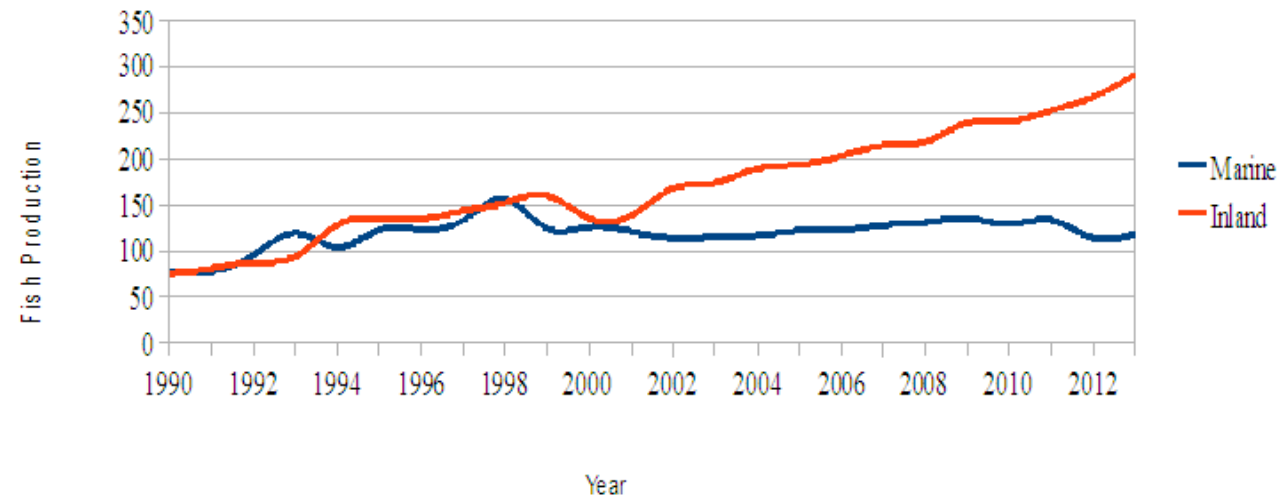

The figure shows that both inland and marine fish production increased in tandem during the pre-WTO period. But in the post-WTO period inland fish production exhibited uninterrupted growth while the production of marine fish grew slowly with high year-to-year variations. It even declined in 2012 and 2013 so much so that production in 2012 was exactly the same as that in 2002. This means that the WTO guidelines have affected the marine fish sector very severely in the post-WTO period. 
A cursory look at the composition of fish production in Odisha as given in Table-4 indicates that the marine fishery sector is characterized by violent growth fluctuations and more so in the post-WTO period while inland fisheries indicate a more or less smooth increasing trend. Hence growth, fluctuations and instability of the marine fishery sector is worth analyzing. Figure-3 portrays the performance of the marine fishery sector in the state - the thick line representing the pre-WTO period and the thin line indicating the post-WTO period.

Figure-3

Marine fish production of Odisha

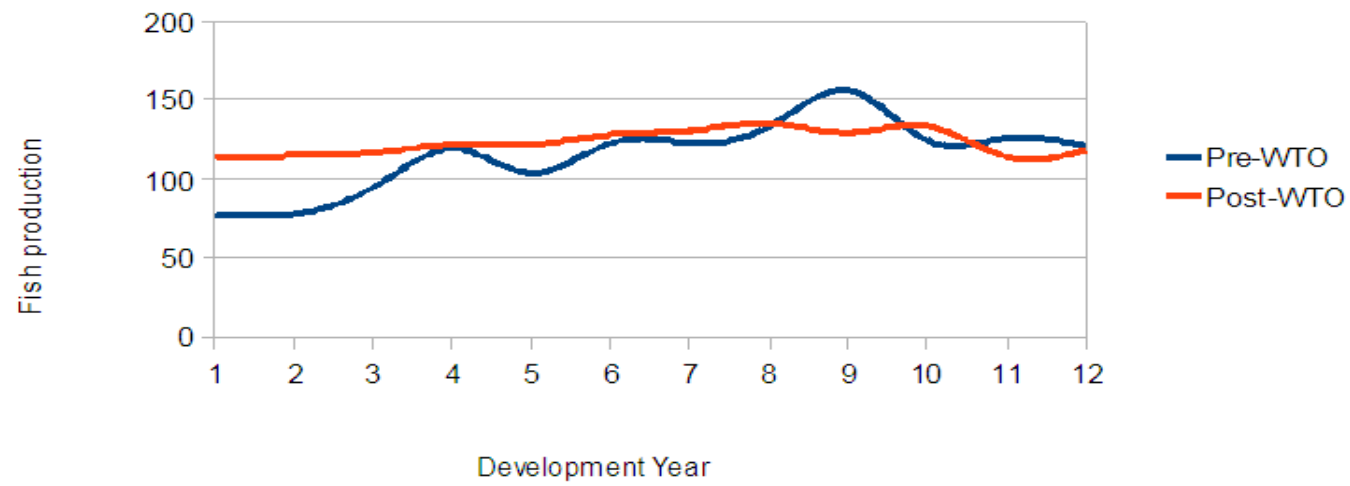

Since the CAGR, CV and instability were higher in the pre-WTO period in comparison to the postWTO period, the two lines in the graph are so shaped. In fact, the greater instability in the pre-WTO period is associated with a higher CAGR and a higher CV. The line depicting marine fish production in the post-WTO period is almost flat indicating suppressed growth and hence lower CV and lower instability. It is well understood that the growth of marine fish production in Odisha has suffered tremendously after the emergence of WTO in the aftermath of the conditionalities.

\subsection{A Comparative Probe}

Comparison of growth performance of the fishery sector in Odisha with the scenario obtaining at the national level has important revelations. It is observed that the CAGR in marine fish production has declined from 1.78 in the pre-WTO period to 1.62 in the post-WTO period at the national level indicating a fall by 9 per cent as against the decline from 3.74 to 0.32 or by 91 per cent for the state. This clearly indicates the severity of the impact of WTO on the state's marine fishery sector. Secondly, marine fish production was affected more seriously in comparison to the inland fish production.

The volatility and instability indicates a still more disheartening scenario. The details are given in Table-5.

\begin{tabular}{|c|c|c|c|c|c|c|}
\hline \multicolumn{4}{|c}{ Table-5 : Instability Index of Marine Fish Production } \\
\hline Period & Years & \multicolumn{2}{|c|}{ Marine } & \multicolumn{3}{|c|}{ Inland } \\
\hline & & India & Odisha & India & Odisha \\
\hline 1 & 2 & 3 & 4 & 5 & 6 \\
\hline Pre-WTO & $1990-2001$ & 1.40 & 4.19 & 1.66 & 3.25 \\
\hline Post-WTO & $2002-2013$ & 1.09 & 1.72 & 1.49 & 2.40 \\
\hline \% Change & & 22.14 & 58.95 & 10.24 & 26.15 \\
\hline
\end{tabular}

The table reveals that the instability in the production of inland fish in India has lowered from 1.66 during the pre-WTO period to 1.49 during the post-WTO period or by 10.24 per cent as against the decline in the case of marine fish production from 1.40 to 1.09 or by 22.14 per cent. In the case of Odisha the estimated decline is from 3.25 to 2.40 or by 26.15 per cent relating to inland fish production and from 4.19 to 1.72 i.e. by 58.95 per cent for marine fish production. Since instability is linked to production of fish, vulnerability is greater in the post-WTO situation due to WTO arrangements both at the national and state levels. The various WTO conditions and the periodical amendments therein which are made to provide greater leverage to developed countries have played a vital role in reducing demand for exports of marine fish from developing countries like India and have forced them to go for realignment. Additionally, the latter countries have inherent constraints of infrastructure, credit restrictions and high interest rates which in consonance with anti-dumping duties have acted as add-ons in restricting their exports. Even though marine exports are largely supply driven in nature the aforesaid constraints have made them a demand driven phenomena and the difficulties of trade alignment have 
only aggravated the impact. Secondly, the magnitude of vulnerability of marine fish production is much greater for Odisha than for the country as a whole indicating that it was more severely affected on account of WTO conditions.

It can be argued that the WTO directives are not different for the state of Odisha from that of India. But the impact varies so widely. Although there is hardly any definite answer to this issue of differential impact, lack of preparedness to accommodate to changing conditions, inadequacy of infrastructure, absence of compensatory mechanism and deficits in administrative expediency which are stronger in Odisha compared to other coastal states make the impact different across states.

\section{Conclusions and Policy Implications}

The emergence of WTO in the international arena has raised some vital issues which are of concern for the developing countries like India. Our analysis of secondary data has shown that in the post-WTO situation, production of marine fish has been subjected to both slow and highly fluctuating growth both at the national level and for Odisha. Surprisingly, instability in production has lowered in the post-WTO situation compared to the pre-WTO period. It is reasoned that low instability is the concomitant of slow growth. However, the growth rate has been slower and instability lower in Odisha's marine fisheries sector relative to the national scenario notwithstanding the fact that both India and Odisha have come under uniform WTO guidelines and conditionalities. The differential impact may be due to differences in infrastructural provisions, preparedness to deal with emerging challenges and such other factors despite the fact that the state has good potential for marine fish production.

It calls for prudent management of the problem of slow and fluctuating growth. But management of marine fisheries is not managing the regulations alone, it should also encompass the roles of various stakeholders including fishermen, traders and exporters. Further, management of marine fisheries is difficult because it is more of an interdependent rather than an independent activity/sector. Natural calamities make production of marine fish quite uncertain too. Increasing production through greater exploration also requires improvement in technology, development of harbours, preservation, storage and transport infrastructure and above all minimum price guarantee. Even when all these provisions are made and the catch increases, then comes exports which are challenged, among other things, by WTO conditionalities and specifications which are clandestinely imposed by the importing developed countries.

Development of the marine fish sector requires multi-dimensional intervention and balance among multiple stakeholders. The requirements in the case of a poor state like Odisha are still more challenging. The following policy implications which are drawn from our exercise may be given shape to moderate the problem.

Primary infrastructure is the key challenge facing the marine fishery sector of Odisha. Government need to facilitate more pre-processing units with state of the art technical knowhow, proper communication system for utilizing the available modern facilities and international standard laboratories need to be established to ensure quality.

Infrastructure for secondary sector marine fishery activities requires improvement of the marketing system and cold storage chains supporting the landing centers in the state including a frozen logistic system through roads and sea routes.

The export sector which is exposed to the international shocks need to be protected through prompt policy making both at national and state levels and provide support for prospective impacts to ensure their minimal extension towards other stakeholders.

NGOs may be involved in educating the preliminary sector through international technical knowhow which will help in designing better export friendly products to fetch better price deals along with proper hygiene ensuring less rejection. Public Private Partnership (PPP) initiatives may also be attracted to this sector.

\section{References:}

[1]. Aswathy, N and Shyam, S.S. (2012). Subsidies in Indian fisheries-Methodological issues and implications for the future., Central Marine Fisheries Research Institute.

[2]. Bhagwati, J. and Srinivasan, T.N. (1999). "Outward-Orientation and Development: Are Revisionists Right?, Yale University. Economic Growth Center, Discussion Paper 806, New Haven, Conn.

[3]. Coppock, J.D. (1962), International Economic Instability, McGraw-Hill, New York

[4]. Cuddy, J. D. A. and Della Valle,P.A. (1978). Measuring the Instability of Time Series Data. Oxford Bulletin of Economics and Statistics, 40 (1), 79-85.

[5]. Economic Survey of Odisha, (2013-14), Government of Odisha

[6]. Handbook of fishery statistics, (2011), Government of India, New Delhi.

[7]. Harper, S., Bevacqua D., Chudnow R., Giorgi S., Guillonneau V., Le Manach F., Sutor T., Sumaila U.R., (2012). Fuelling the Fisheries Subsidy Debate: Agreements, Loopholes and Implications. Fisheries Research, 113 (1), 143-146.

[8]. Jeyanthi, P and Gopal, N. (2012). Growth and Instability in Indian Frozen Scampi Export, Fishery Technology, 49,187-192.

[9]. Veena, J. (2005). Environmental Regulation and Food Safety: Studies of Protection and Protectionism, International Development Research Centre and Edward Elgar Publishing Limited, UK and USA. 
[10]. Jinji, N. (2011). Fisheries Subsidies and Management in Open Economies, Discussion Paper No. E-11-004, October-2011

[11]. Kaushik, A. and Shahib, M. (2001). Environmental requirements and India's export: An impact analysis, RGICS working paper series 25, Rajiv Gandhi Foundation, New Delhi.

[12]. Kuruvila, A. and Shyam, S.S, (2012). Implications for WTO Agreement in Fisheries Sector- A Conceptual Framework, Central Marine Fisheries Research Institute, Cochin.

[13]. Mac Bean, A. I. (1966). Export instability and economic development, George Allen and Unwin, London.

[14]. Massell, B. F. (1970). Export instability and economic structure, American Economic Review, 60, (4). 618-630.

[15]. Mitra, A. K. (1990). Agricultural production in Maharashtra: Growth and instability in the context of new technology. Economic and Political Weekly, 25(52), A146-A164.

[16]. Mohanty, S. S. ( 2013). Technological Advance in the Marine Fisheries Sector in Odisha in the Era of Liberalisation. Published in lokkatha.com on 02.11 .2013

[17]. Naik,D. (2001). An economic analysis of marine fish marketing in Orissa, Research Project submitted to Orissa University of Agriculture and Technology, Bhubaneshwar, Orissa.

[18]. Nair, K.S. (2006). Ornamental fish trade in the Indian context. In: Kurup et al. (eds.), Souvenir, Aquashow 2006. Dept. of Fisheries, Govt. of Kerala, 61-70.

[19]. Oyakhilomen, O and Zibah, R.G. (2013). Fishery Production and Economic Growth in Nigeria: Pathway for sustainable economic development, Journal of Sustainable Development in Africa $(15(2), 2013)$ Clarion University of Pennsylvania, Clarion, Pennsylvania.

[20]. Parthasarathy, G. (1984). Growth rates and fluctuations of agricultural production: A District-wise analysis in Andhra Pradesh. Economic and Political Weekly, 19(26), A74 - A84.

[21]. Parvathy, P. and Rajasenan, D. (2012). From Market Concentration to Market Diversification: WTO and the Marine Products Exports from Kerala- Using ARIMA Method, Developing Country Studies, 2,(6), 19-28.

[22]. Pillai, N.G.K. and Katiha, P.K. (2004). Evolution of Fisheries and Aquaculture in India, Central Marine Fisheries Research Institute, Cochin, India: 240

[23]. Punnathara, C.J. (2009). Shrimp Exporters turn innovative, The Hindu Business Line, January.

[24]. Raghuram, G. and Asopa, V.N. (2008). Issues in Infrastructure for Export of Marine Products from India, Indian Institute of Management, Ahmedabad, W.P. No. 2008-07-04.

[25]. Sarada, C., Ravisankar, T., Krishnan, M. and Anandanarayanan, C. (2006). Indian Seafood Exports: Issues of Instability, Commodity Concentration and Geographical Spread, Indian Journal of Agricultural Economics, 61(2).238.

[26]. Sathiadhas, R., Najmudeen, T., Prathap, M. and Sangeetha, K. (2009). Break-even Analysis and Profitability of Aquaculture Practices in India. Asian Fisheries Science, 22 (2). pp. 667-680.

[27]. Shiyani, R.L. (2002). Fisheries development in India: the political economy of unsustainable development, Journal of the Gokhale Institute of Politics and Economics, Pune, 44 (2), 189-198.

[28]. Shyam, S.S. (2013). Fishery sector in India: Export Trade Perspectives beyond WTO. Central Marine Fisheries Research Institute, Cochin.

[29]. Shyam, S.S. and Narayanakumar, R. (2012). Manual on World Trade Agreements and Indian Fisheries Paradigms: A Policy Outlook, Central Marine Fisheries Research Institute,Cochin.

[30]. Singh, A.J. and Byerlee, D. (1990). Relative variability in wheat yields across countries and over time. Journal of Agricultural Economics 41(1):21-32

[31]. Tendulkar, S. (2000). Indian Export and Economic Growth Performance in Asian Perspective, Indian Council for Research on International Economic Relations, New Delhi, Working Paper No. 54

[32]. Vijayagopal, P. and Shankar, T.V. (2012). WTO agreements and quality concerns in Indian Fisheries, Central Marine Fisheries Research Institute, Cochin.

[33]. Weber, A. and Sievers, M. (1985). Instability in world food production: statistical analysis, graphical presentation, and interpretation. Publisher: Wissenschaftsverlag Vauk Kiel KG. 